\title{
Susceptibility of sixteen strawberry (Fragaria $\times$ ananassa) cultivars to Drosophila suzukii (Matsumura, 1931) (Diptera: Drosophilidae) in Southwestern Spain
}

\author{
Susceptibilidad de dieciséis variedades de fresa (Fragaria $\times$ ananassa) a Drosophila \\ suzukii (Matsumura, 1931) (Diptera: Drosophilidae) en el suroeste de España \\ IDSERGIO PÉREZ-GUERRERO ${ }^{1 *}$; iDlaura AVIVAR'; \\ iDOLIVIA CRUZ'; iDJOSÉ M. MOLINA ${ }^{1}$
}

\begin{abstract}
'IFAPA, Instituto Andaluz de Investigación y Formación Agraria, Pesquera, Alimentaria y de la Producción Ecológica, Centro "Las Torres”, sergio.perez@
\end{abstract} juntadeandalucia.es, laura.avivar@juntadeandalucia.es,olivia.cruz@juntadeandalucia.es, josem.molina@juntadeandalucia.es_

\begin{abstract}
*Corresponding author
Sergio Pérez-Guerrero, IFAPA, Centro "Las Torres", Ctra. Sevilla - Cazalla Km. 12,2, Sevilla, España.sergio.perez@juntadeandalucia.es

Suggested citation

PEREZ-GUERRERO, S.; AVIVAR, L.; CRUZ, O.; MOLINA, J. M. 2022. Susceptibility of sixteen strawberry (Fragaria $\times$ ananassa) cultivars to Drosophila suzukii (Matsumura, 1931) (Diptera: Drosophilidae) in Southwestern Spain. Revista Colombiana de Entomología 48 (1): e11288. https://doi.org/10.25100/socolen. v48i1.11288
\end{abstract}

Recibido: 21-May-2021

Aceptado: 24-Nov-2021

Publicado: 03-Mar-2022

Revista Colombiana de Entomología ISSN (Print): 0120-0488

ISSN (On Line): 2665-4385

https://revistacolombianaentomologia.univalle.edu.co

Open access

(c) (1) (2) (2) BY-NC-SA 4.0

Publishers: Sociedad Colombiana de Entomología SOCOLEN (Bogotá, D. C., Colombia) https://www.socolen.org.co

Universidad del Valle (Cali, Colombia)

https://www.univalle.edu.co

(C) 2021 Sociedad Colombiana de Entomología SOCOLEN y Universidad del Valle - Univalle
Abstract: The susceptibility of the newest and most used strawberry cultivars to the Spotted Wing Drosophila (SWD) in southwestern Spain was evaluated. Sixteen strawberry cultivars were selected ('Calderón', 'Calinda', 'Charlene', 'Flaminia', 'Flavia', 'Fortuna', 'Marisol', 'Marquis', 'Melissa', 'Palmeritas', 'Petaluma', 'Plared0955', 'Primoris', 'Rábida', 'Rociera' and 'Sabrina') and no-choice tests were carried out under laboratory conditions. In addition, fruit weight, fruit firmness, ${ }^{\circ} \mathrm{Brix}, \mathrm{pH}$, protein content and total phenolic content were recorded in order to assess what influence these variables had on SWD infestation. The sixteen strawberry cultivars tested in this study were susceptible to SWD, although significant differences have been found among them. The mean number of emerged adults in 'Calderon' and 'Plared0955' were significantly higher than in the other tested cultivars. Significant differences in developmental time were also detected among these cultivars and both sexes but these were unrelated to the level of infestation. No correlation between fruit quality and chemical traits and infestation parameters was found. Our results detected significant differences in the susceptibility of strawberry cultivars in southwestern Spain to SWD; these may help to design IPM programs and to make recommendations for strawberry production, one of the most important crops in southern Europe.

Keywords: Invasive pest, berry crops, pest-resistant, Spotted Wing Drosophila, sustainable agriculture.

Resumen: Se evaluó la susceptibilidad a Drosphila suzukii de las variedades de fresa de nueva introducción y más utilizadas en el suroeste de España. Se seleccionaron dieciséis variedades de fresa ('Calderón', 'Calinda', 'Charlene', 'Flaminia', 'Flavia', 'Fortuna', 'Marisol', 'Marquis', 'Melissa', 'Palmeritas', 'Petaluma', 'Plared0955', 'Primoris', 'Rábida', 'Rociera' and 'Sabrina') con las que se llevaron a cabo ensayos de no elección en condiciones de laboratorio. Además, para cada una de ellas se estimó el peso del fruto, firmeza, ${ }^{\circ} \mathrm{Brix}, \mathrm{pH}$, contenido en proteínas y contenido total de fenoles para estudiar la influencia de estas variables sobre el nivel de infestación. Las dieciséis variedades estudiadas fueron susceptibles a $D$. suzukii, si bien se encontraron diferencias significativas entre ellas. El número medio de adultos emergidos en las variedades 'Calderon' y 'Plared0955' fue significativamente superior al resto de las variedades. Se detectaron también diferencias significativas en el tiempo de desarrollo entre variedades y sexos, sin que tuviera relación con el nivel de infestación. Finalmente, no se encontró correlación entre las características fisico-químicas de las diferentes variedades y ningún parámetro de infestación. Nuestros resultados ponen de manifiesto diferencias significativas en la susceptibilidad a D. suzukii entre las variedades de fresa presentes en el suroeste de España; lo que pueden ayudar al diseño de programas de manejo integrado de la plaga y a realizar recomendaciones para la producción de fresa, uno de los cultivos más importantes del sur de Europa.

Palabras clave: Agricultura sostenible, cultivo de frutos rojos, drosófila de alas manchadas, plagas invasivas, resistencia a plagas. 


\section{Introduction}

Drosophila suzukii (Matsumura, 1931), the Spotted Wing Drosophila (SWD) is an emerging and invasive pest, native to south-east Asia, that was first recorded in Europe and continental North America in 2008 and currently affects a wide range of important crops, especially berries (Calabria et al. 2010; Walsh et al. 2011; Cini et al. 2012; Asplen et al. 2015). SWD infests healthy, ripening fruits, inserting eggs with its serrated ovipositor (Walsh et al. 2011) and its larvae feed and develop in fruits, which are rendered unsellable, resulting in a dramatic reduction in fruit production and financial losses in soft skinned fruits (Walsh et al. 2011; Silva dos Santos 2014; Andreazza et al. 2016). Average yield reductions attributed to SWD may range from $33 \%$ to $50 \%$ depending on which crop is affected (Bolda et al. 2010; Goodhue et al. 2011).

Strawberry, Fragaria x ananassa Duchesne (Rosaceae) is one of the most widely consumed berries worldwide with one of the highest growth rates in consumption among fruit and vegetables in the last decades. World strawberry production exceeded 8 million tonnes in 2018 with China being the world's largest producer, representing $35.5 \%$ of global production followed by the USA (15.6\%), Mexico (7.8\%), Turkey $(5.3 \%)$, and Egypt (4.4\%). Spain, with a harvested area of 7032 ha, and total production of 3,44,679 tonnes (4.1\%), ranks sixth (FAO 2020). More than $95 \%$ of Spanish strawberry production is located in the province of Huelva (southwest). The climatic and soil characteristics are exceptionally good in the area for strawberry production. Strawberries in Huelva are usually grown as an annual crop, under unheated, high plastic tunnels (Spanish tunnels), whose sides can be rolled up, on raised beds covered with black plastic and fed by drip irrigation. In this planting system, fresh, short-day strawberry cultivars, plants from high elevation nurseries are used. The production season goes from October to June, with fruits harvested from December. This semi-open cultivation system benefits growers as it helps to produce fresh strawberries from the start of the season, thereby enabling international markets to be supplied at an early stage (López-Aranda 2008). In recent years, there has been a focus on developing new strawberry cultivars better adapted to local conditions in southwestern Spain. Currently, over 40 different varieties of strawberry (L. Miranda, pers.com.) can be found in Huelva. However, studies on susceptibility/resistance to insects (the inability or ability of a plant variety to restrict the growth and/or development of a specified pest; https://www.worldseed.org) are not common in the development, agronomic evaluation and recommendations for these varieties, in which production and marketing criteria predominate. 'Fortuna', 'Rociera', 'Rábida', 'Primoris' and 'Calinda' are the most used strawberry cultivars in Huelva (Medina et al. 2019). In addition, new varieties are constantly being produced and tested in order to meet consumer demand and optimize production.

Strawberries are among the preferred hosts for SWD (Lee et al. 2011; Walsh et al. 2011; Cai et al. 2019) and significant damage and economic losses are caused by this pest in fruit production (EPPO 2022; Arnó et al. 2016; Orhan et al. 2016). SWD management in strawberries usually entails using adult-oriented chemical treatments (Bruck et al. 2011; Burrack et al. 2015). Organophosphates, pyrethroids and spinosyns have been greatly effective against SWD adults (Bruck et al. 2011; Van Timmeren and Isaacs 2013). However, intensive use of synthetic-organic insecticides and spi- nosyns may induce pests resistant in them (Bruck et al. 2011) and be detrimental to beneficial arthropods (Roubos et al. 2014) as well as being incompatible with organic management. Moreover, overuse may violate the Maximum Residue Limit (MRL) zero tolerance policy for berry markets. Therefore, alternative methods seem necessary for producing more environmentally-friendly crops (Cini et al. 2012; Asplen et al. 2015). The development and deployment of pest-resistant cultivars or tolerant varieties can be an effective approach for reducing damage caused by SWD and nurturing environmentally-friendly crop management as an alternative to chemical control (Sharma and Ortiz 2002). Moreover, an analysis of cultivar susceptibility to pests can also help improve management strategies for growers, identify trap plants and provide particularly significant alternative techniques for organic producers (Zehnder et al. 2007; Cini et al. 2012; Asplen et al. 2015; Poyet et al. 2015).

The susceptibility of berries and other crops cultivars (blueberries, raspberries, blackberries, strawberries, cherries and grapes) to SWD have been analyzed in previous studies (Lee et al. 2011; Linder et al. 2014; Ioriatti et al. 2015; Gong et al. 2016; Baser et al. 2018; Molina et al. 2020). However, there has been little research on strawberries in which the susceptibility of different cultivars to SWD have been analysed. Lee et al. (2011) carried out choice and no-choice tests with 'Totem' and 'Hood' cultivars in order to determine susceptibility at different stages of ripeness to egg laying and SWD development. However, they did not compare susceptibility between these two cultivars. Likewise, Arnó et al. (2016) demonstrated that SWD was able to oviposit in red, blush, or green 'Albion' and 'Candonga' cultivars whose host suitability varied at different stages of ripeness in 'Candonga' but not in 'Albion'. Živković et al. (2019) showed statistically higher susceptibility to drosophilids (including SWD) in the 'Albion' cultivar compared to 'Portola' and 'San Andreas'. Finally, there are several known genome sequences of strawberry species and hybrids, which provide the opportunity to correlate data on cultivar susceptibility with genotype variations, which will help develop new cultivars or improve existing ones. Gong et al. (2016) investigated the rate of adult SWD emergence from the fruits of 107 accessions of Fragaria identifying at least three of them with significantly reduced fly emergence. Later, Bräcker et al. (2020) noted that one of these resistant accessions displayed unusually enriched methyl anthranilate and found this compound to be a potent agonist against SWD egg development.

In this study, we screened sixteen strawberry cultivars (the most used as well as those recently introduced in southwestern Spain) for their suitability to SWD. Our aims were to elucidate whether SWD infestation varied among these cultivars, and to corroborate the relationships between some organoleptic characteristics of the fruit and certain SWD performance traits.

\section{Materials and methods}

SWD experimental colony. SWD adult females employed in the tests came from an experimental colony established in the IFAPA Laboratory of Entomology, 'Las Torres' (Alcalá del Río, Seville; Spain). The colony originated from larvae collected in field-infested raspberries in Huelva (southwestern Spain). The population was reared on berry fruits (mainly blueberries and raspberries). Adults were kept in $30 \mathrm{~cm}^{3}$ cages 
(BugDorm ${ }^{\circledR} 1$; Bio-Quip Products Inc., Rancho Rodríguez, CA; USA) at $22 \pm 1{ }^{\circ} \mathrm{C}, 60 \pm 5 \% \mathrm{RH}$, and $16: 8 \mathrm{~h}$ light: dark cycle, and fed with brewer's yeast, and $10 \% \mathrm{w} / \mathrm{v}$ sugar- $\mathrm{dH}_{2} \mathrm{O}$. To prevent endogamy, and ensure genotypic diversity, individuals emerging from naturally infested fruits were introduced into the colony several times during rearing.

Non-choice tests. We conducted laboratory no-choice tests on sixteen strawberry cultivars: 'Calderón', 'Calinda', 'Charlene', 'Flaminia', 'Flavia', 'Fortuna', 'Marisol', 'Marquis', 'Melissa', 'Palmeritas', 'Petaluma', 'Plared0955', 'Primoris', 'Rábida', 'Rociera' and 'Sabrina'. They were maintained in experimental plots at the IFAPA Experimental Station of El Cebollar (Moguer, Huelva, southwestern Spain) from which fully ripe, sellable fruits (BBCH-Scale: 87. Main harvest: more fruits coloured; Meier et al. 1994) for tests were collected. The plot was managed in the typical agricultural method for strawberries used in the area (see above, López-Aranda, 2008). The strawberry fruits were carefully selected in order to ensure the same phenological stage. Fruits were subsequently rinsed with $\mathrm{dH}_{2} \mathrm{O}$, and examined before testing under a stereomicroscope (Leica MZ6, Leica Microsystems, Germany) to ensure there was no bruising, nor signs of SWD infestation. Ten replicates per cultivar (a total of 160 tests) were performed where in each replicate, one strawberry fruit was exposed to three SWD females (5-12 days old) randomly selected from the experimental colony, confined in individual $30 \mathrm{~cm}^{3}$ cages (see above). After $24 \mathrm{~h}$ the fruits were removed from the cages, and individually held in polystyrene rearing flasks lined with filter paper and covered with a mesh lid. The flasks were kept at $22 \pm 1{ }^{\circ} \mathrm{C}, 60.0 \pm 5.0 \%$ RH, and 16:8 h light: dark cycle, and were checked for adult emergence for up to 21 days.

For each replicate and cultivar, we recorded the number of emerged adults, sex and days to complete cycle. The time for adult fly emergence was measured in days post-exposure (DPE), with day 1 being the day of exposure itself. After 21 days, each fruit was dissected and the remaining immature stages of the SWD recovered were counted. Adult emergence and fruit dissection accurately estimates actual SWD infestation when counting eggs directly is unreliable or not possible (Shaw et al. 2019). Thus, our measurements of SWD performance included number of adults, apparent emergence rate and number of developing SWD (larvae + pupae) after 21 days and development time.

Fruit analysis. Strawberry fruit analyses were carried out on 10 fruits (6 in the case of total phenolic and protein content) from the same sample used in the tests. Weight, firmness, $\mathrm{pH}$, and sugar content $\left({ }^{\circ}\right.$ Brix) were measured. For firmness, a TR penetrometer (FDP 500®, Effegi, Italy) fitted with a 1.0 $\mathrm{mm}$ diameter probe was used. Two measurements were taken in the equatorial part of each fruit as they lay on a flat, horizontal surface. The mean penetration force $\left(\mathrm{g} \mathrm{mm}^{-2}\right)$ obtained from both measurements was used in the analyses. Sugar content was determined by squeezing the fruits and placing a drop of the juice on a portable refractometer (Eclipse ${ }^{\circledR}$, Bellingham \& Stanley Ltd., UK). This was expressed as ${ }^{\circ}$ Brix. Afterwards, each fruit was crushed, and a Crimson $\mathrm{pH}-\mathrm{meter}$ basic 20 (Alella, Spain) was used to determine their $\mathrm{pH}$.

Total phenolic and protein content were determined. For each cultivar, the fruit extract was prepared with $2 \mathrm{~g}$ of plant material that was weighed and extracted with a mixture of methanol: $0.1 \% \mathrm{HCl}$ in $50 \mathrm{~mL}$, homogenized using a Polytron ${ }^{\circledR}$ (PT2000, Kinematica AG, Luzern, Switzerland) and filtered in a vacuum using a Kitasato, Büchner funnel, and Whatman \#4 filter paper.

Total phenolic content was determined by the Folin-Ciocalteu method as gallic acid equivalents (GAE)/100 $\mathrm{g}$ fw (Allen, 1989). Flavonoids in fruit extracts were determined

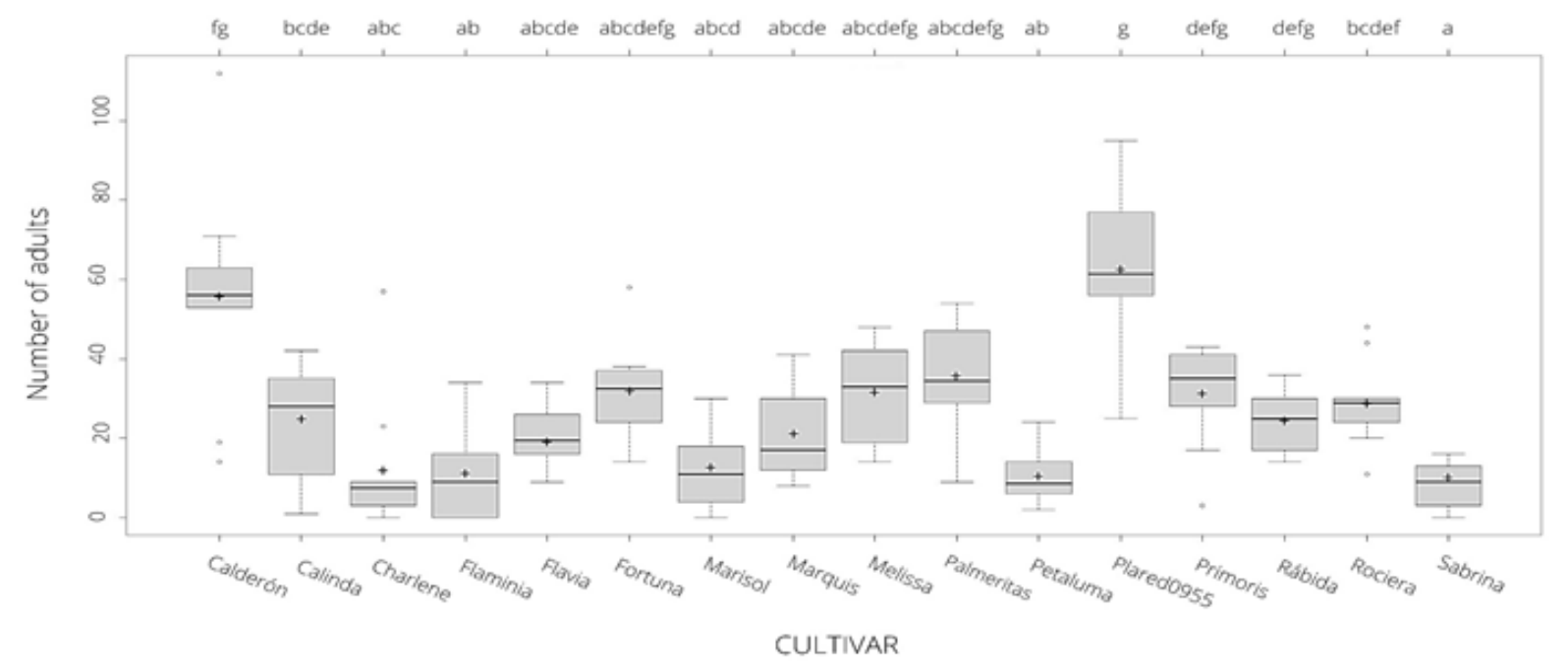

Figure 1. Number of emerged adults in the sixteen strawberry tested cultivars. Cross and line represent the mean and the median, respectively. Outliers are represented by the dots. Different letters denote a significant difference based on generalized linear models (GLMs) among cultivars in which alpha $=0.05$. 
using the colorimetric method of Dewanto et al. (2002), whose results were expressed as $\mathrm{mg}$ of catechin equivalents (CE)/100 g fw. Anthocyanin content was determined by the pH-differential method (Giusti and Wrolstad 2001), whose results were expressed as mg pelargonidin-3-glucoside equivalents $(\mathrm{P} 3 \mathrm{G}) / 100 \mathrm{~g}$ fw. Finally, for protein determination, fruit flesh was extracted with $0.1 \% \mathrm{NaOH}$, following the method described in Jones et al. (1989), whose results were expressed as $\mathrm{g}$ of protein per $100 \mathrm{~g} \mathrm{fw}$.

Statistical procedures. All analyses were carried out using R v. 3.1.3 software (R Core Team 2021). Since the normality and linearity of residuals did not match for number of adults emerged and number of larvae and pupae, generalized linear models (GLMs) were ran to test the effects different cultivars had on fruit infestation. GLMs were carried out separately, including total number of adults, number of developing SWD (larvae + pupae) as dependent variables, and cultivars as the factor fitted to a Poisson distribution with a log link function. Where differences were detected by GLM, multiple comparisons, post-hoc Tukey HSD tests $(p<0.05)$ were performed using the 'glht' function in the 'multcomp' package (Hothorn et al. 2008). In addition, we checked the models for overdispersion and residual distribution using the DHARMa package (Hartig 2020). When overdispersion was detected, the models were fitted to a negative binomial with a $\log$ link function.

Given that days of development, and texture and chemical traits of berries matched normality and linearity of residuals, lineal models (LMs) were used to determine differences in strawberry traits among cultivars. LMs with interaction terms were performed including cultivars and adult sex as factors, and days of development as the dependent variable using the ' $I \mathrm{~m}$ ' function from the 'nmle' package (Pinheiro et al. 2021). When statistical differences were detected, the 'glht' function was also used, as explained above. The correlation between strawberry attributes and SWD infestation data were conducted using a non-parametric Spearman's rank correlation coefficient $(\rho)$.

\section{Results}

Significant differences in the number of emerged adults were found among the tested cultivars (LRT $\chi^{2}=1297.1, \mathrm{df}=15, p$ $<0.001$ ). Post-hoc homogenous groups and levels of infestation of the tested cultivars are shown in Fig. 1. 'Calderon' and

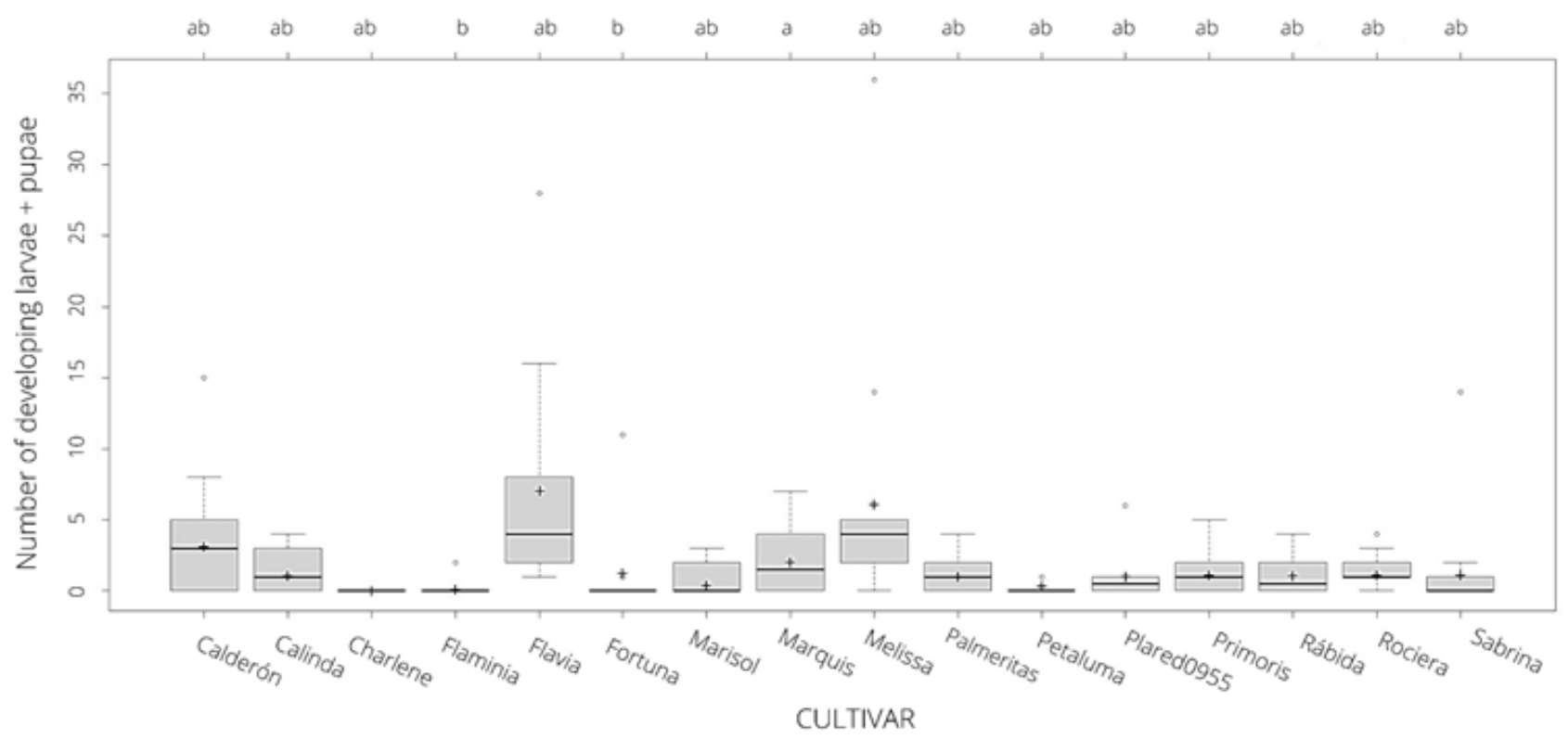

Figure 2. Number of developing (larvae + pupae) detected in the sixteen strawberry tested cultivars. Cross and line represent the mean and the median, respectively. Outliers are represented by the dots. Different letters denote a significant difference based on generalized linear models (GLMs) among cultivars in which alpha $=0.05$.

'Plared0955' cultivars displayed the highest number of adults per fruit with an average of $55.8 \pm 8.5$ and $62.8 \pm 6.3$ respectively. In contrast, 'Sabrina' and 'Petaluma' cultivars showed the lowest levels of infestation with an average of $8.1 \pm 1.8$ and $10.4 \pm 2.1$ adults per fruit, respectively. In addition, three cultivars presented less than 20 adults per fruit ('Charlene', 'Flaminia' and 'Marisol'), five between 20 and 30 ('Flavia', 'Calinda', 'Marquis', Rábida and 'Rociera') and four between 30 and 40 ('Fortuna', 'Melissa', 'Palmeritas' and 'Primoris').
Significant differences in developing SWD (larvae + pupae) per fruit were also detected among the tested cultivars $\left(\right.$ LRT $\left.\chi^{2}=85.1, \mathrm{df}=15, p<0.001\right)$. 'Flavia' and 'Melissa' cultivars presented the highest mean number of developing SWD (7.2 \pm 2.7 and $7.3 \pm 3.4$, respectively) with significant differences in comparison with 'Charlene', 'Flaminia' and 'Marisol' that presented the lowest mean number of developing $\operatorname{SWD}(0.0 \pm 0.0,0.4 \pm 0.3$ and $0.8 \pm 0.3$, respectively) (Fig. 2).

Mean developmental time (expressed as DPE) was 14.00 


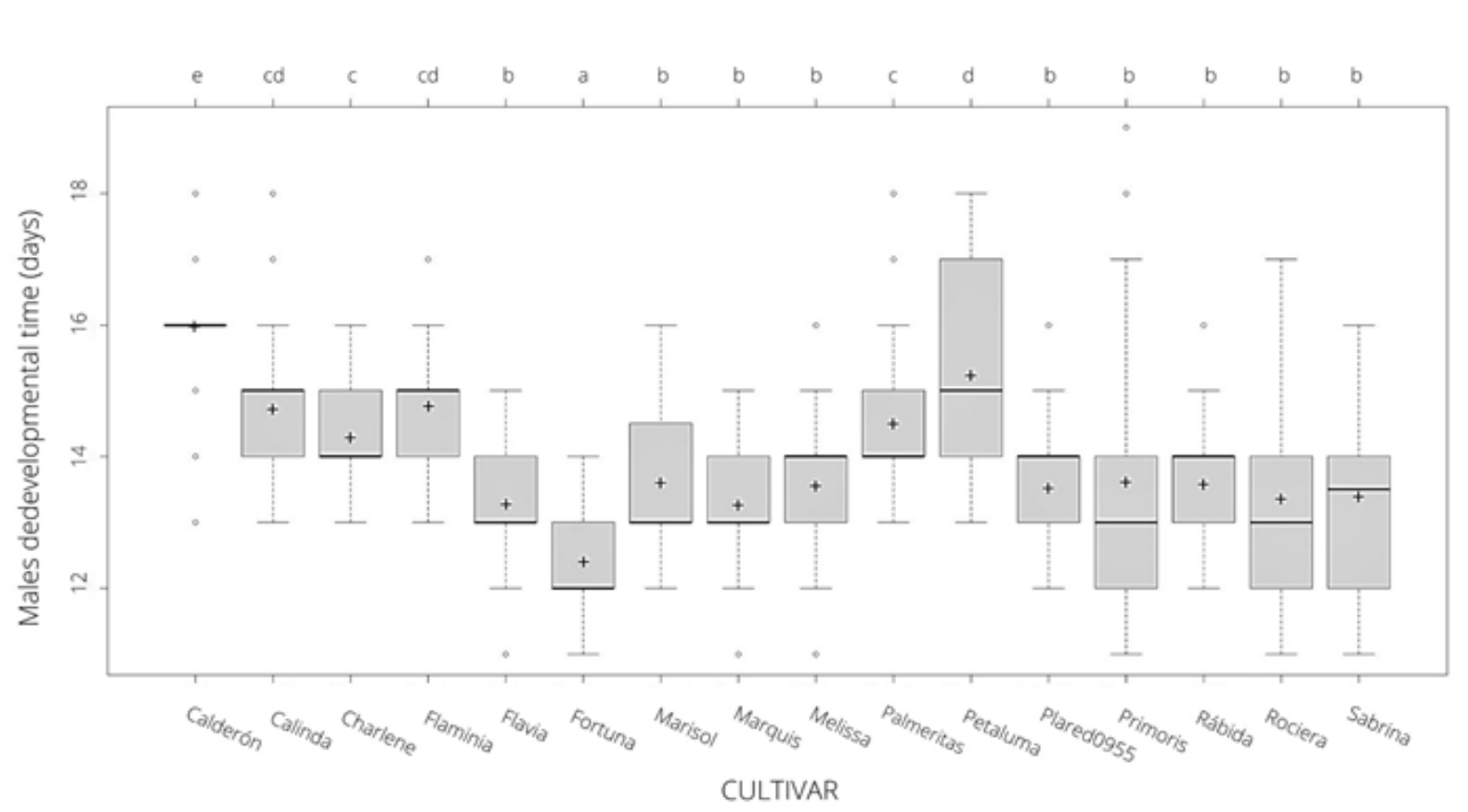

A

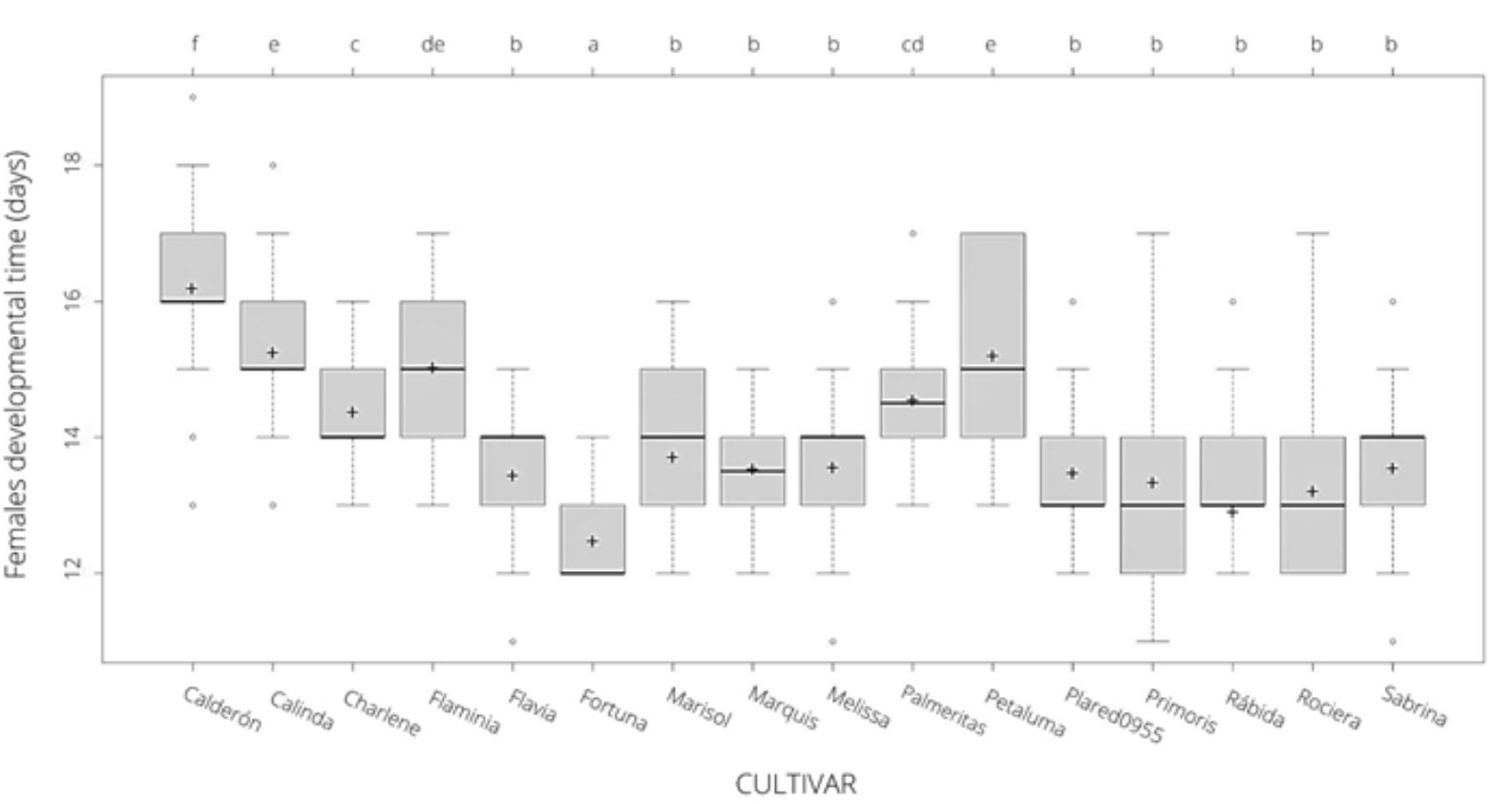

Figure 3. Mean developmental time (expressed as days post exposure) for males (A) and females (B) in the sixteen strawberry tested cultivars. Cross and line represent the mean and the median, respectively. Outliers are represented by the dots. Different letters denote a significant difference based on generalized linear models (GLMs) among cultivars in which alpha $=0.05$.

\pm 0.02 days. The LMs revealed significant differences in DPE among the tested cultivars $\left(\mathrm{F}_{15: 4110}=277.3 ; p<0.001\right)$ between males and females $\left(\mathrm{F}_{1: 4110}=7.4 ; p<0.01\right)$ and in the interaction between these factors $\left(\mathrm{F}_{15: 4110}=2.8 ; p<0.001\right)$. In fact, DPE was shorter in males (13.95 \pm 0.03 days) than in females (14.02 \pm 0.03 days). Consequently, when both sexes were analysed separately, significant differences in developmental time among the cultivars were found for males $\left(\mathrm{F}_{15: 2033}\right.$
$=117.0 ; p<0.001)$ and females $\left(\mathrm{F}_{15: 2077}=166.1 ; p<0.001\right)$. Regarding the former, 'Fortuna' cultivar showed the lowest mean developmental time (12.4 \pm 0.05 days) with significant differences with respect to the other cultivars (Fig. 3A). In contrast, 'Calderón' and 'Petaluma' presented the highest time for males $(15.9 \pm 0.06$ and $15.2 \pm 0.2$ days, respectively) differing significantly between them (Fig. 3A). In addition, with 'Calinda', 'Charlene', 'Flaminia' and 'Palmeritas' there 
Table 1. Fruit traits (mean $\pm \mathrm{SE}$ ) measured from sixteen strawberry cultivars. Size $\left(\mathrm{F}_{15,144}=5.2, p<0.001\right)$, Firmness $\left(\mathrm{F}_{15,144}=8.6, p<0.001\right)$, Sugar content $\left(\mathrm{F}_{15,144}=24.2, p<0.001\right), \mathrm{pH}\left(\mathrm{F}_{15,144}=17.4, p<0.001\right)$, Protein content $\left(\mathrm{F}_{15,80}=12.0, p<0.001\right)$, Total Fenolics $\left(\mathrm{F}_{15,80}=35.6, p<0.001\right)$, Anthocyanins $\left(\mathrm{F}_{15,80}=246.9 ; p<0.001\right)$ and Flavonoids $\left(\mathrm{F}_{15,80}=31.5 ; p<0.001\right)$. Letters denote significant differences by Tukey's HSD $(p<0.05)$.

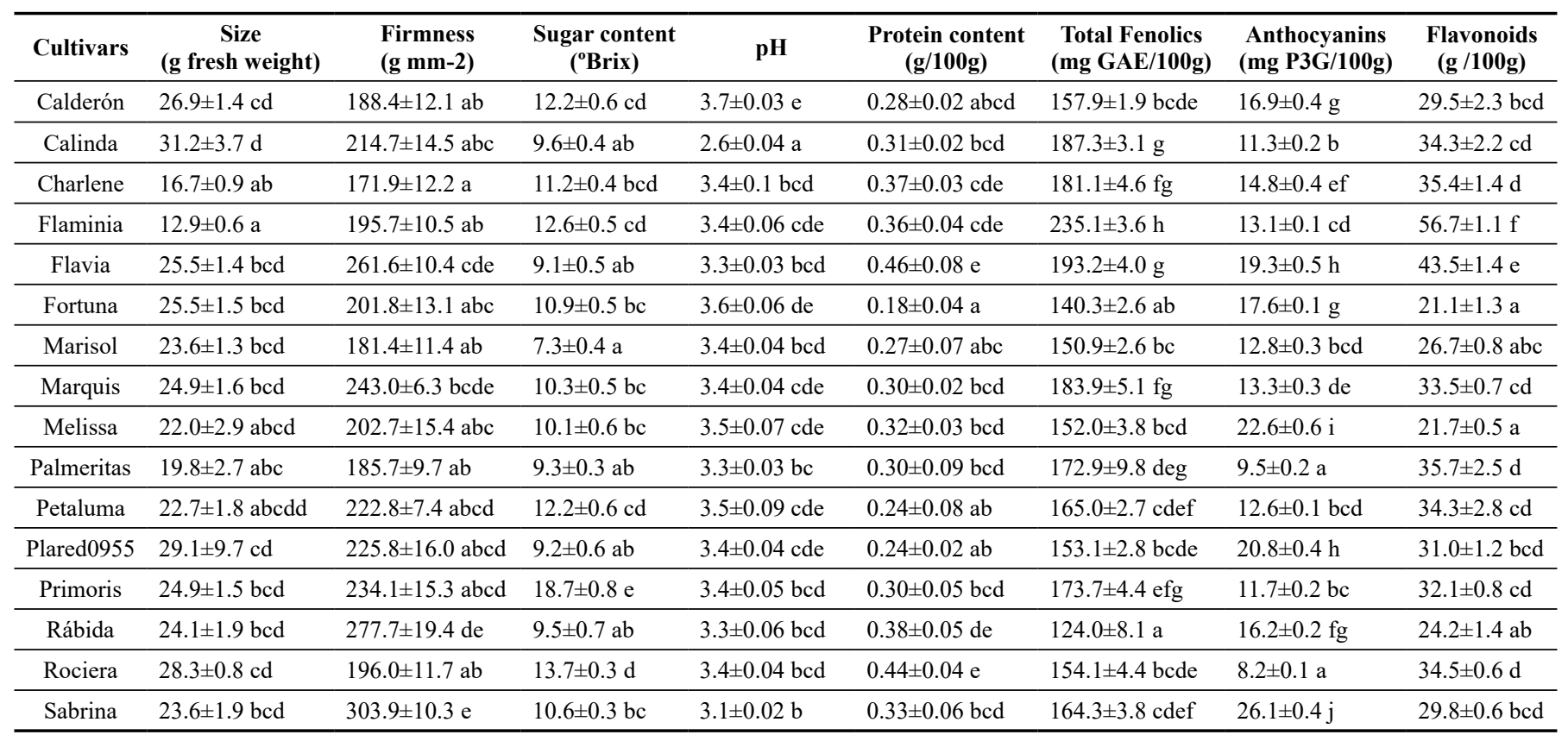

were no significant differences in these times, which ranged from $14.7 \pm 0.08$ to $14.3 \pm 0.09$ days (Fig. 3A). Finally, there were no significant differences among the other nine cultivars, whose values ranged between $13.2 \pm 0.07$ and $13.6 \pm 0.1$ days (Fig. 3A). A similar pattern was obtained for females. Once again, 'Fortuna' displayed the lowest time (12.5 \pm 0.05 days $)$ with significant differences with respect to the other cultivars (Fig. 3B). 'Calderón' (16.2 \pm 0.06 days) followed by 'Petaluma', 'Calinda' 'Flaminia', 'Palmeritas' and 'Charlene' (15.2 $\pm 0.09,15.2 \pm 0.02,15.0 \pm 0.1,14.6 \pm 0.08$ and $14.4 \pm 0.09$ days, respectively) presented the highest time for females. Finally, the other nine cultivars presented no significant differences, ranging from $13.2 \pm 0.08$ to $13.7 \pm 0.2$ days (Fig. 3B).

Strawberries from the different cultivars varied in their quality and chemical attributes (Table 1). Fruit size (expressed as $\mathrm{g}$ fresh weight) differed significantly $\left(\mathrm{F}_{15,144}=5.2\right.$, $p<0.001)$ with 'Calinda' showing the highest value and 'Flaminia' the lowest. Firmness also differed significantly $\left(\mathrm{F}_{15,144}=\right.$ $8.6, p<0.001$ ) with the minimum being $171.9 \pm 12.2 \mathrm{~g} \mathrm{~mm}^{-2}$, for 'Charlene', and the maximum, $303.9 \pm 10.3 \mathrm{~g} \mathrm{~mm}^{-2}$, for 'Sabrina'. Results also showed significant differences in sugar content $\left(\mathrm{F}_{15,144}=24.2, p<0.001\right)$. 'Primoris' and 'Marisol' had the highest and lowest values respectively $(18.7 \pm 0.8$ and 7.3 $\pm 0.4)$. Similarly, there was great variation in their $\mathrm{pH}$ values $\left(\mathrm{F}_{15,144}=17.4, p<0.001\right)$ which ranged from $2.6 \pm 0.04$ in 'Calinda' to $3.7 \pm 0.03$ in 'Calderón'. Protein content and total phenolics also varied significantly among cultivars $\left(\mathrm{F}_{15,80}=\right.$ $12.0, p<0.001$ and $\mathrm{F}_{15,80}=35.6, p<0.001$, respectively). Protein content ranged from $0.18 \pm 0.04 \mathrm{~g} / 100 \mathrm{~g}$ in 'Fortuna' to $0.46 \pm 0.08 \mathrm{~g} / 100 \mathrm{~g}$ in 'Flavia'. 'Calinda' showed the highest total phenolics value and 'Rábida' the lowest. Anthocianyns and flavonoids also varied significantly $\left(\mathrm{F}_{15,80}=246.9 ; p<\right.$ $0.001 ; \mathrm{F}_{15,80}=31.5 ; p<0.001$, respectively). Sabrina and Rociera presented the highest and the lowest values of anthocya- nins, respectively. Finally, flavonoids ranged from $21.1 \pm 1.3$ $\mathrm{g} / 100 \mathrm{~g}$ in 'Fortuna' to $56.7 \pm 1.1 \mathrm{~g} / 100 \mathrm{~g}$ in 'Flaminia'.

No correlation between fruit quality and chemical attributes and infestation parameters (number of emerged adults, developing SWD and DPE) was found ( $p<0.05$ in all cases). Likewise, there was no correlation between infestation (number of emerged adults and number of developing SWD) and DPE $(p<0.05$ in all cases).

\section{Discussion}

The sixteen strawberry cultivars tested in this study showed susceptibility to SWD, and suitability for larval development, although notable differences were found among them. Few previous studies have analysed susceptibility or identified pest-resistance in strawberry cultivars. Lee et al. (2011) and Arnó et al. (2016) carried out choice and no-choice tests with 'Totem' and 'Hood', and 'Albion' and 'Candonga' cultivars, respectively, in order to determine susceptibility at different stages of ripeness for egg laying and SWD development. However, they did not compare susceptibility between cultivars. Likewise, Bernardi et al. (2017), in a no-choice bioassay, using the strawberry cultivar, 'Albion', reported significant differences in fruit susceptibility to SWD infestation at different stages of ripening, but in a choice bioassay, females preferred to oviposit on ripe fruits. Gong et al. (2016) found great variation in emergence among 107 strawberry accessions ranging from 0 to 16 emerged adults per fruit. In addition, differences in the emergence of SWD adults has been reported for fruit collected in the field from 'Albion', 'San Andreas', and 'Portola' strawberry cultivars (Živković et al. 2019). According to the levels of infestation obtained herein, the most susceptible cultivar ('Plared0955') presented 7.75 times more emerged adults than the least susceptible one ('Sabrina'), indicating notable variation between the cultivars tes- 
ted. Currently, 'Fortuna' and 'Rociera' are those most grown in southwestern Spain, comprising over $65 \%$ of total cultivated strawberries (Medina et al. 2019). In this study, these two cultivars displayed a mid-level of infestation with at least eight cultivars showing lower values. Thus, it is clear that further research and field observations are required to confirm these differences in susceptibility, especially before new cultivars are established in any given area.

Significant differences were also detected in developmental time between males and females and among tested cultivars. Recently, such differences were also detected among blueberries cultivars, but not between males and females (Molina et al. 2020). In addition, Gong et al. (2016) found differences in adult emergence time ranged from 13 to 17 days after exposure. These variations in developmental time might have been linked to hight density of larvae developing inside the fruit. In this respect, Bezerra Da Silva et al. (2019) found a decrease in egg-pupa development times for SWD in blueberries due to intraspecific competition under laboratory conditions. However, in this paper, no correlation between infestation and developmental time was found. For instant, the most susceptible cultivar ('Plared0955') displayed intermediate developmental times. Thus, other factors must explain these differences in developmental times among cultivars.

Although strawberries from the different cultivars varied in their quality and chemical attributes, no correlation between fruit quality, chemical traits and infestation parameters was found. The fruit characteristics were responsible for the differences in preference and performance among fruits remains unclear (Olazcuaga et al. 2019). In previous studies, several of the physical and/or chemical attributes of the berries were related to SWD infestation (Lee et al. 2011; Kinjo et al. 2013). Links were found to fruit firmness or penetration force (Burrack et al. 2013; Ioriatti et al. 2015; Baser et al. 2018; Molina et al. 2020), fruit size (Gong et al. 2016; Stringer et al. 2017) and $\mathrm{pH}$ (Lee et al. 2016; Little et al. 2017; Rodríguez-Saona et al. 2018; Molina et al. 2020). Moreover, the brix level of the fruits (Lee et al. 2011, 2016; Stringer et al. 2017) was a contributing factor in the susceptibility of the fruits to SWD infestation. However, other authors yielded variable results, whose conclusions were not always consistent (Little et al. 2017; Pelton et al. 2017; Rodríguez-Saona et al. 2018). In addition, other elements such as proteins and lipids are known to affect development time and reproduction (Royes and Robertson 1964; Tu and Tatar 2003; Olazcuaga et al. 2019). Results obtained herein found no correlation between fruit quality and the chemical attributes measured, and SWD infestation. Therefore, other factors may be key to explaining differences in susceptibility to SWD among the strawberry cultivars tested. For instance, some strawberry compounds (e. g. methyl anthranilate) have recently been identified as limiting factors in SWD development and, to a certain extent, affect the egg hatching rate (Bräcker et al. 2020). Further research and field observations are required in order to shed light on which fruit attributes determine differences in susceptibility to SWD in strawberry cultivars in southwestern Spain. Different levels of infestation may also be due to the repellent effect of ingredients or volatiles of the cultivars or to the different development conditions of the instars in the fruit (with equally strong oviposition). This point could not be elucidated in this work since the proportion of hatched eggs could not be recorded. Therefore, experimental design of future research must take this factor into account in order to determine in detail which processes explain the differences in susceptibility among cultivars. In practice, the significant differences in susceptibility detected herein could help improve SWD management in southern Spain. In fact, the cultivars that have shown a lower level of infestation ('Sabrina', 'Petaluma') are not among those most used by growers in southern Spain (Medina et al. 2019), which indicates that there is room for improvement in SWD management with the use of the appropriate cultivar. Finally, efforts are necessary to reconcile susceptibility studies with agricultural and socio-economic factors involved in the selection of cultivars by growers.

In summary, the sixteen strawberry cultivars tested in this study showed susceptibility to SWD, with significant differences in the range of infestation. 'Calderon' and 'Plared0955' cultivars displayed the highest number of adults per fruit, in contrast to 'Sabrina' and 'Petaluma' that showed the lowest level of infestation. Significant differences were also detected in developmental time between males and females and among the cultivars. Unlike in previous studies, no correlation between quality and chemical fruit traits, and infestation parameters was found. However, it must be stressed that strawberry cultivars in the field should be selected on the basis of an analysis of berry demand and agricultural and socio-economic factors, whose results do not necessarily have to coincide with those reported herein. Since strawberry farming is constantly adapting to market demand, more laboratory and field studies in this area are required in order to analyse how planting strawberry cultivars less susceptible to SWD would help to design IPM programmes.

\section{Acknowledgements}

The authors wish to thank Asunción Sánchez (IFAPA'Las Torres') for helping us in the laboratory assays and Mar Zamora for helping us in the figures design.

\section{Literature cited}

ALLEN S. E. 1989. Chemical analysis of ecological materials. $2^{\text {a }}$ Ed. Blackwell Scientific Publications, Oxford, UK, 380 p.

ANDREAZZA, F.; HADDI, K.; OLIVEIRA, E. E.; FERREIRA, J. A. M. 2016. Drosophila suzukii (Diptera: Drosophilidae) Arrives at Minas Gerais State, a main strawberry production region in Brazil. Florida Entomologist 99 (4): 796-798. https://doi. org/10.1653/024.099.0439

ARNÓ, J.; SOLÀ, M.; RIUDAVETS, J.; GABARRA, R. 2016. Population dynamics, non-crop hosts, and fruit susceptibility of Drosophila suzukii in Northeast Spain. Journal of Pest Science 89: 713-723. https://doi.org/10.1007/s10340-016-0774-3

ASPLEN, M.K.; ANFORA, G.; BIONDI, A.; CHOI, D. S.; CHU, D.; DAANE, K. M.; GIBERT, P.; GUTIERREZ, A. P.; HOELMER, K. A.; HUTCHINSON, W. D.; ISAACS, R.; JIANG, Z. L.; KÁRPÁTI, Z.; KIMURA, M. T.; PASCUAL, M.; PHILIPS, C. R.; PLANTAMP, C.; PONTI, L.; VÉTEK, G.; VOGT, H.; WALTPON, V. M.; YU, Y.; ZAPPALÀ, L.; DESNEUX, N. 2015. Invasion biology of Spotted Wing Drosophila (Drosophila suzukii) a global perspective and future priorities. Journal of Pest Science 88: 469-494. https://doi.org/10.1007/s10340-015-0681-z

BASER, N.; BROUTOU, O.; VERRASTRO, V.; PORCELLI, F.; IORIATTI, C.; ANFORA, G.; MAZZONI, V.; ROSSI-STACCONI, M. V. 2018. Susceptibility of table grape varieties grown in South-eastern Italy to Drosophila suzukii. Journal of Applied Entomology 142 (5): 465-472. https://doi.org/10.1111/jen.12490 BEZERRA DA SILVA, C.; PARK, K. R.; BLOOD, R. A.; WALTON, V. M. 2019. Intraspecific competition affects the pupation beha- 
vior of Spotted-Wing Drosophila (Drosophila suzukii). Scientific Reports 9: 7775. https://doi.org/10.1038/s41598-019-44248-6

BERNARDI, D.; ANDREAZZA, F.; BOTTON, M.; BARONIO, C. A.; NAVA, D. E. 2017. Susceptibility and interactions of Drosophila suzukii and Zaprionus indianus (Diptera: Drosophilidae) in damaging strawberry. Neotropical Entomology 46: 1-7. https:// doi.org/10.1007/s13744-016-0423-9

BOLDA, M. P.; GOODHUE, R. E.; ZALOM, F. G. 2010. Spotted Wing Drosophila: Potential economic impact of newly established pest. Giannini Foundation of Agricultural Economics, University of California. Agricultural and Resource Economics Update 13 (3): 5-8. https://giannini.ucop.edu/publications/ are-update/issues/2010/13/3/spotted-wing-drosophila-p/

BRÄCKER, L. B.; GONG, X.; SCHMID, C.; DAWID, C.; ULRICH, D.; PHUNG, T.; LEONHARD, A.; AINSWORTH, J.; OLBRICHT, K.; PARNISKE, M.; GOMPEL, N. 2020. A Strawberry Accession With Elevated Methyl Anthranilate fruit concentration is naturally resistant to the pest fly Drosophila suzukii. PLoS ONE 15 (6): e0234040. https://doi.org/10.1371/journal. pone. 0234040

BRUCK, D. J.; BOLDA, M.; TANIGOSHI, L.; KLICK, J.; KLEIBER, J.; DE FRANCESCO, J.; GERDEMAN, B.; SPITLER, H. 2011. Laboratory and field comparisons of insecticides to reduce infestation of Drosophila suzukii in berry crops. Pest Management Science 67 (11): 1375-1385. https://doi.org/10.1002/ ps. 2242

BURRACK, H. J.; FERNANDEZ, G. E.; SPIVEY, T.; KRAUS, D. A. 2013. Variation in selection and utilization of host crops in the field and laboratory by Drosophila suzukii Matsumara (Diptera: Drosophilidae), an invasive frugivore. Pest Management Science 69 (10): 1173-1180. https://doi.org/10.1002/ps.3489

BURRACK, H. J.; ASPLEN, M.; BAHDER, L.; COLLINS, J.; DRUMMOND, F. A.; GUÉDOT, C.; ISAACS, R.; JOHNSON, D.; BLANTON, A.; LEE, J. C.; LOEB, G.; RODRIGUEZ-SAONA, C.; VAN TIMMEREN, S.; WALSH, D.; MCPHIE, D. R. 2015. Multistate comparison of attractants for monitoring Drosophila suzukii (Diptera: Drosophilidae). Environmental Entomology 44 (3): 704-712. https://doi.org/10.1093/ee/nvv022

CAI, P.; SONG, Y.; YI, C.; ZHANG, Q.; XIA, H.; LIN, J.; ZHANG, H.; YANG, J.; JI, Q.; CHEN, J. 2019. Potential host fruits for Drosophila suzukii: Olfactory and oviposition preferences and suitability for development. Entomologia Experimentalis et Applicata 167 (10): 880-890. https://doi.org/10.1111/eea.12840

CALABRIA, G.; MACA, J.; BÄCHLI, G.; SERRA, L.; PASCUAL, M. 2012. First records of the potential pest species Drosophila suzukii (Diptera: Drosophilidae) in Europe. Journal of Applied Entomology 136 (1-2): 139-147. https://doi.org/10.1111/j.14390418.2010.01583.x

CINI, A.; IORIATTI, C.; ANFORA, G. 2012. A Review of the invasion of Drosophila suzukii in Europe and a draft research agenda for integrated pest management. Bulletin of Insectology 65 (1): 149-160. http://www.bulletinofinsectology.org/pdfarticles/ vol65-2012-149-160cini.pdf

DEWANTO, V.; WU, X.; ADOM, K. K.; LIU, R. H. 2002. Thermal processing enhances the nutritional value of tomatoes by increasing total antioxidant activity. Journal of Agricultural and Food Chemistry 50: 3010-3014. https://doi.org/10.1021/jf0115589

EPPO (2022) Drosophila suzukii. EPPO datasheets on pests recommended for regulation. https://gd.eppo.int/taxon/DROSSU/datasheet [Accessed on: 10 January 2022].

FAO. 2020. FAOSTAT. Food and Agriculture Organization of the United Nations, Rome, Italy.

GIUSTI, M.M.; WROLSTAD, R.E. 2001. Characterization and measurement of anthocyanins by UV-visible spectroscopy. Current Protocols in Food Analytical Chemistry 00: F1.2.1-F1.2.13. https://doi.org/10.1002/0471142913.faf0102s00

GONG, X.; BRÄCKER, L.; BÖLKE, N.; PLATA, C.; ZEITLMAYR, S.; METZLER, D.; OLBRICHT, K.; GOMPEL, N.; PARNISKE, M. 2016. Strawberry Accessions with reduced Droso- phila suzukii emergence from fruits. Frontiers in Plant Science 7 (1880): 1-7. https://doi.org/10.3389/fpls.2016.01880

GOODHUE, R. E.; BOLDA, M.; FARNSWORTH, D.; WILLIAMS, J. C.; ZALOM, F. G. 2011. Spotted Wing Drosophila infestation of California strawberries and raspberries: Economic analysis of potential revenue losses and control costs. Pest Management Science 67 (11): 1396-1402. https://doi.org/10.1002/ps.2259

HARTIG, F. 2020. DHARMa: Residual Diagnostics for Hierarchical (Multi-Level / Mixed) Regression Models. R package version 0.3.3.0. https://CRAN.R-project.org/package=DHARMa

HOTHORN, T.; BRETZ, F.; WESTFALL, P. 2008. Simultaneous inference in general parametric models. Biometrical Journal 50 (3): 346-363. https://doi.org/10.1002/bimj.200810425

IORIATTI, C.; WALTON, V.; DALTON, D.; ANFORA, G.; GRASSI, A.; MAISTRI, S.; MAZZONI, V. 2015. Drosophila suzukii (Diptera: Drosophilidae) and its Potential Impact To Wine Grapes During Harvest in two cool climate wine grape production regions. Journal of Economic Entomology 108 (3): 1148-1155. https://doi.org/10.1093/jee/tov042

JONES, C. G.; HARE, J. D.; COMPTON, S. J. 1989. Measuring plant protein with the Bradford Assay 1. Evaluation and standard method. Journal of Chemical Ecology 15: 979-992. https://doi. org/10.1007/BF01015193

KINJO, H.; KUNIMI, Y.; BAN, T.; NAKAI, M. 2013. Oviposition efficacy of Drosophila suzukii (Diptera: Drosophilidae) on different cultivars of blueberry. Journal of Economic Entomology 106 (4): 1767-1771. https://doi.org/10.1603/EC12505

LEE, J. C.; BRUCK, D. J.; CURRY, H.; EDWARDS, D.; HAVILAND, D. R.; VAN STEENWYK, R. A.; YORGEY, B. M. 2011. The susceptibility of small fruits and cherries to the Spotted Wing Drosophila, Drosophila suzukii. Pest Management Science 67 (11): 1358-1367. https://doi.org/10.1002/ps.2225

LEE, J. C.; DALTON, D. T.; SWOBODA-BHATTARAI, K. A.; BRUCK, D. J.; BURRACK, H. J.; STRIK, B. C.; WOLTZ, J. M.; WALTON, V. M. 2016. Characterization and manipulation of fruit susceptibility to Drosophila suzukii. Journal of Pest Science 89: 771-780. http://dx.doi.org/10.1007/s10340-015-0692-9

LINDER, C.; MARTIN, C.; LABOISSE, S.; CHATELAIN, P. G.; KEHRLI, P. 2014. Susceptibility of various grape cultivars to Drosophila suzukii and other vinegar flies. Integrated protection and production in Viticulture. IOBC-WPRS Bulletin 105: 219-224. https://www.iobc-wprs.org/pub/2013 WG_Viticulture_meeting_Ascona_CH/38-Linder.pdf

LITTLE, C. M.; CHAPMAN, T. W.; MOREAU, D. L.; HILLIER, N. K. 2017. Susceptibility of selected boreal fruits and berries to the invasive Pest Drosophila suzukii (Diptera: Drosophilidae). Pest Management Science 73 (1): 160-166. https://doi.org/10.1002/ ps. 4366

LÓPEZ-ARANDA, J. M. 2008. El cultivo de la fresa en Huelva. In La fresa de Huelva. Junta de Andalucía, Consejería de Agricultura y Pesca, Sevilla, España. https://www.juntadeandalucia. es/export/drupaljda/1337161077LIBRO_FRESA_HUELVA.pdf

MEDINA, J. J.; MIRANDA, L.; SORIA, C̄.; GÓMEZ-MORA, J. A. 2019. Informe Técnico "Distribución varietal en el cultivo de fresa en Huelva. Campaña 2018-2019". Sevilla. Consejería de Agricultura, Ganadería, Pesca y Desarrollo Sostenible, Instituto de Investigación y Formación Agraria y Pesquera. 1-8 p. Digital format (e-book). https://www.juntadeandalucia. es/agriculturaypesca/ifapa/servifapa/registro-servifapa/6dd741e8-f54a-498e-a5a5-aa62dcaaf637

MEIER, U.; GRAF, H.; HESS, M.; KENNEL, W.; KLOSE, R.; MAPPES, D.; SEIPP, D.; STAUSS, R.; STREIF, J.; VAN DEN BOOM, T. 1994. Phänologische Entwick-lungsstadien des Kernobstes (Malus domestica Borkh. und Pyrus communis L.), des Steinobstes (Prunus-Arten), der Johannisbeere (Ribes-Arten) und der Erdbeere (Fragaria x ananassa Duch.). Nachrichtenbl. Deut. Pflanzenschutzd. 46 (7): 141-153. https://www.openagrar. de/receive/openagrar_mods_00067136 
MOLINA, J. M.; AVIVAR, L.; PÉREZ-GUERRERO, S. 2020. Short communication: Laboratory evaluation of nine highbush blueberry cultivars susceptibility to Drosophila suzukii (Matsumura, 1931) in the Southwestern Spain. Spanish Journal of Agricultural Research 18 (2): e10SC03. https://doi.org/10.5424/ sjar/2020182-16100

OLAZCUAGA, L.; RODE, N. O.; FOUCAUD, J.; FACON, B.; RAVIGNÉ, V.; AUSSET, A.; LEMÉNAGER, N.; LOISEAU, A.; GAUTIER, M.; ESTOUP A.; HUFBAUER, R. A. 2019. Oviposition preference and larval performance of Drosophila suzukii (Diptera: Drosophilidae), Spotted-Wing Drosophila: Effects of fruit identity and composition. Environmental Entomology 48 (4): 867-881. https://doi.org/10.1093/ee/nvz062

ORHAN, A.; ASLANTA, R.; ÖNDER, B.S.; TOZLU G. 2016. First Record of the invasive vinegar fly Drosophila suzukii (Matsumura) (Diptera: Drosophilidae) from Eastern Turkey. Turkish Journal of Zoology 40: 290-293. https://doi.org/10.3906/zoo1412-25

PELTON, E.; GRATTON, C.; GUÉDOT, C. 2017. Susceptibility of cold hardy grapes to Drosophila suzukii (Diptera: Drosophilidae). Journal of Applied Entomology 141 (8): 644-652. https:// doi.org/10.1111/jen.12384

PINHEIRO, J.; BATES, D.; DEBROY, S.; SARKAR, D.; R CORE TEAM. 2021. nlme: Linear and nonlinear mixed effects models . R package version 3.1-152, <URL:https://CRAN.R-project.org $/$ package $=$ nlme $>$.

POYET, M.; LE ROUX, V.; GIBERT, P.; MEIRLAND, A.; PRÉVOST, G.; ESLIN, P. 2015. The wide potential trophic niche of the Asiatic fruit fly Drosophila suzukii: the key of its invasion success in temperate Europe? PLoS ONE 10 (11): e0142785. https://doi.org/10.1371/journal.pone.0142785

R CORE TEAM. 2021. R: A language and environment for statistical computing. R Foundation for Statistical Computing, Vienna, Austria. http://www.R-project.org/.

RODRIGUEZ-SAONA, C.; CLOONAN, K.R.; SANCHEZ-PEDRAZA, F.; ZHOU, Y.; GIUSTI, M. M.; BENREY, B. 2018. Differential susceptibility of wild and cultivated blueberries to an invasive frugivorous pest. Journal of Chemical Ecology 45 (3): 286-297. https://doi.org/10.1007/s10886-018-1042-1

ROUBOS, C. R.; RODRIGUEZ-SAONA, C.; HOLDCRAFT, R.; MASON, K. S.; ISAACS, R. 2014. Relative toxicity and residual activity of insecticides used in blueberry pest management: mortality of natural enemies. Journal of Economic Entomology 107 (1): 277-285. https://doi.org/10.1603/ec13191

ROYES, W. V.; ROBERTSON, F. W. 1964. The Nutritional Requirements and Growth Relations of Different Species of Drosophila. Journal of Experimental Zoology 156 (1): 105-135. https://doi. org $/ 10.1002 /$ jez. 1401560108

SHARMA, H. C.; ORTIZ, R. 2002. Host plant resistance to insects: an eco-friendly approach for pest management and environment conservation. Journal of Environmental Biology 23 (2): 111-135. https://pubmed.ncbi.nlm.nih.gov/12602847/

SHAW, B.; CANNON, M.; BUSS, D.; CROSS, J.; BRAIN, P.; FOUNTAIN, M. 2019. Comparison of extraction methods for quantifying Drosophila suzukii (Diptera: Drosophilidae) Larvae in soft- and stone-fruits. Crop Protection 124: 104868. https:// doi.org/10.1016/j.cropro.2019.104868

SILVA DOS SANTOS, R. S. 2014. Drosophila suzukii (Matsumura, 1931) (Diptera: Drosophilidae) atacando frutos de morangueiro no Brasil. Enciclopédia Biosfera 10 (18): 4005-4011. https:// conhecer.org.br/ojs/index.php/biosfera/article/view/2760

STRINGER, S. J.; SAMPSON, B. J.; HUMMER, K. E. 2017. Screening small fruit germplasm for resistance to southern populations of invasive Spotted Wing Drosophila, SWD (Diptera: Drosophilidae). Acta Horticulturae 1180: 45-52. https://doi.org/10.17660/ ActaHortic.2017.1180.7

TU, M. P.; TATAR, M. 2003. Juvenile diet restriction and the aging and reproduction of adult drosophila melanogaster. Aging Cell 2 (6): 327-333. https://doi.org/10.1046/j.1474-9728.2003.00064.x
VAN TIMMEREN, S.; ISAACS, R. 2013. Control of Spotted Wing Drosophila, Drosophila suzukii, by specific insecticides and by conventional and organic crop protection programs. Crop Protection 54: 126-133. https://doi.org/10.1016/j.cropro.2013.08.003

WALSH, D. B.; BOLDA, M. P.; GOODHUE, R. E.; DREVES, A. J.; LEE J.; BRUCK, D. J.; WALTON, V. M.; O’NEAL, S. D.; ZALOM, F. G. 2011. Drosophila suzukii (Diptera: Drosophilidae): Invasive Pest of ripening soft fruit expanding its geographic range and damage potential. Journal of Integrated Pest Management 2 (1): G1-G7. https://doi.org/10.1603/IPM10010

ZEHNDER, G.; GURR, G. M.; KÜHNE, S.; WADE, M. R.; WRATTEN, S. D.; WYSS, E. 2007. Arthropod pest management in organic crops. Annual Review of Entomolology 52: 57-80. https:// doi.org/10.1146/annurev.ento.52.110405.091337 .

ŽIVKOVIĆ, P.; DURALIJA, B.; BARIĆ, B.; SELJAK, G.; LEMIC, D.; MEŠIC, A. 2019. The development of drosophilid species (Diptera, Drosophilidae) in different strawberry cultivars. European Journal of Horticultural Science 84 (1): 48-52. https:// www.pubhort.org/ejhs/84/1/7/index.htm

\section{Origin and funding}

This work was supported by the Project AVA.301201.6 (Obj. 3), AVA201601.10 (Line 2) from IFAPA CAPDR Junta de Andalucía (Spain).

\section{Author contribution}

$S P G, J M M, O C$ and $L A$ designed and performed the tests. SPG and JMM wrote the paper. All authors contributed to the statistical analyses, read and approved the final manuscript.

\section{Conflict of de interest}

The authors participating in this publication made significant contributions to the manuscript; all authors agree and express that there are no conflicts of interest in this study. 